\title{
Prevalence and Risk Factors of Anaemia Among Pregnant women in Nigeria
}

\author{
F.I. Buseri ${ }^{1}$, E. K. Uko ${ }^{2}$, Z. A. Jeremiah ${ }^{*, 1}$ and E.A. Usanga ${ }^{2}$ \\ ${ }^{1}$ Department of Medical Laboratory Science, Niger Delta University, Wilberforce Island, Bayelsa State, Nigeria \\ ${ }^{2}$ Department of Haematology and Blood Transfusion University of Calabar Teaching Hospital Calabar, Nigeria
}

\begin{abstract}
To assess the prevalence and risk factors of anaemia in pregnancy and recommend a cut-off value for antenatal women in developing countries, a cross sectional study was carried in the University of Port Harcourt Teaching Hospital, Port Harcourt, a 523 bed tertiary health care institution in Nigeria. 1371 apparently healthy asymptomatic pregnant women visiting the antenatal clinic for the first time were enrolled for the study. Another 60 age-matched non-pregnant apparently healthy women served as controls. Haemoglobin concentration, malaria, human immunodeficiency virus (HIV)S, haemoglobin electrophoretic pattern and C-reactive protein as marker of infection were investigated using standard haematological and serological procedures. Anaemia in pregnancy $(\mathrm{Hb}<11.0 \mathrm{~g} / \mathrm{dl})$ and $(\mathrm{Hb}<10.0 \mathrm{~g} / \mathrm{dl})$ were found to be $23.2 \%$ and $6.7 \%$ respectively. The aetiology of anaemia was found to be multifactorial; $40.2 \%$ had anaemia of infection, 20.3\% had Plasmodium falciparum alone, $8.5 \%$ had HIV alone, 2.5\% had HIV and malaria parasite co-infection; $8.9 \%$ undetermined infections and $0.6 \%$ had sickle cell anaemia. There is moderate prevalence of anaemia in pregnancy in this part of the world. Since the mean $\mathrm{Hb}$ value of the pregnant women in this study was $11.62 \pm 1.21 \mathrm{~g} / \mathrm{dl}$ and the pregnant women with $\mathrm{Hb}$ values around $10 \mathrm{~g} / \mathrm{dl}$ are apparently healthy, a cut-off value of $10.0 \mathrm{~g} / \mathrm{dl}$ may be considered ideal for defining anaemia in pregnancy in developing countries.
\end{abstract}

Keywords: Anaemia in pregnancy, Risk factors of anaemia, Prevalence, Nigeria.

\section{INTRODUCTION}

Anaemia in pregnancy remains one of the most intractable public health problems in developing countries. It is extremely common and although not always shown to have a causal link, severe anaemia contributes to maternal morbidity and mortality [1-6]. Anaemia, even when mild to moderate affects the sense of well-being resulting in fatigue, stress and reduced work productivity [7]. During labour, women with severe anaemia are less able to endure moderate blood loss and as a consequence are at a higher risk of requiring a blood transfusion during delivery [8], thus exposing patients unnecessarily to the risk of infection with human immunodeficiency virus (HIV) and other blood borne pathogens [9].

It is estimated that anaemia may be responsible for as much as $20 \%$ of all maternal deaths in sub-Saharan Africa through three main mechanisms. Firstly, anaemia makes women more susceptible to deaths from haemorrhage by lowering their haematological reserves for blood loss especially at birth. Severe anaemia is associated with increased susceptibility to infection due to lowered resistance to disease, and $\mathrm{Hb}<4 \mathrm{~g} / \mathrm{dl}$ is also associated with high risk of cardiac failure, particularly during delivery or soon after, making the woman likely to die if unable to reach good health facilities immediately $[10,11]$.

Several studies have shown an association between anaemia and maternal mortality from both hospital data and community based studies $[12,13]$. In addition, severe maternal anaemia may impair the oxygen delivery to the fetus and

*Address correspondence to this author at the Department of Medical Laboratory Sciences, Niger Delta University, Wilberforce Island, Bayelsa State, Nigeria; Tel: 234-803-370-5675; E-mail: fibuseri@yahoo.com interfere in normal intra-uterine growth, resulting in intrauterine growth retardation, still birth, low birth weight and neonatal deaths $[14,15]$.

Infants of anaemic women are born with reduced iron stores and are at risk of anaemia during infancy and increased risk of infant morbidity and mortality $[16,17]$. Reduction of anaemia during pregnancy is therefore a key component of safe motherhood. This report is to the best of our knowledge, the first large scale study of anaemia in pregnancy and risk factors associated with it in Port Harcourt City of Nigeria. It is hoped that the outcome of this study will help to improve the quality of antenatal care in developing countries.

\section{MATERIALS AND METHODOLOGY}

Design

A cross-sectional study was used.

\section{Setting}

The study was conducted at the University of Port Harcourt Teaching Hospital (UPTH), Port Harcourt, a government tertiary health care institution with a total of 523 bed spaces and outpatients clinics. Port Harcourt is a cosmopolitan city with a population of about 2 million inhabitants. The geographical location is latitude $4^{\circ} 31^{\prime}-5^{\circ} 31^{\prime}$ and longitude $6^{\circ} 30^{\prime}-7^{\circ} 21^{\prime}$. It is the state capital of Rivers State and Nigeria's second largest commercial and industrial centre and has the second busiest seaport in Nigeria. Thus, apart from the indigenes, there are various ethnic groups living in Port Harcourt. The subjects therefore, represent subgroups of Nigerian pregnant women. 
Table 1. Characteristics of all Pregnant Women Studied and Non-Pregnant Control Women

\begin{tabular}{|c|c|c|c|c|}
\hline Age (yrs) & $29.37 \pm 4.67$ & $15-48$ & $26.07 \pm 0.68$ & $18-40$ \\
\hline Gestational age (wks) & $21.64 \pm 7.81$ & $2-40$ & Nil & Nil \\
\hline Haemoglobin $(\mathrm{Hb})(\mathrm{g} / \mathrm{dl})$ & $11.62 \pm 1.21$ & $4.3-17.0$ & $12.57 \pm 0.11$ & $10.0-14.3$ \\
\hline
\end{tabular}

\section{Study Population}

The study population consisted of 1371 apparently healthy pregnant women residing in Port Harcourt, Nigeria who visited the Antenatal clinic of the University of Port Harcourt Teaching Hospital, Port Harcourt between May and August 2005 for the first time. They were aged 15-48 years with differing gestational age and parity. All subjects were offered confidential pre-test HIV counseling and thereafter informed consent was obtained for blood sample collection. Information on demographic data, maternal age, gestational age, parity, history of previous transfusion and surgery and educational as well as socioeconomic status were collected from all subjects.

\section{Methodology \\ Collection of Blood Samples}

A standard clean venipuncture technique was used to collect $6 \mathrm{ml}$ of blood from each subject from the antecubital or dorsal vein between 9.00 and 12.00 noon, of which, $2 \mathrm{ml}$ was dispensed into a dipotassium EDTA anticoagulant tube and $4 \mathrm{ml}$ into a dry plain plastic tube free of iron. Blood samples were collected before the subjects were prescribed haematinics and antimalarial drugs as part of their antenatal prophylaxis. Control non-pregnant subjects had their blood specimens collected prior to their menstrual periods. Sera derived from the plain tubes were used to determine, Creactive protein (CRP) and HIV screening. The anticoagulated samples were used for the determination of haemoglobin concentration, haemoglobinopathies and malaria parasites.

\section{Laboratory Assessment of Haematologic and Serologic Parameters}

Haemoglobin concentration was determined by the cyanmethaemoglobin method as described by Babara and Bates [18] and as recommended by the International Committee for Standardization in Haematology (ICSH) [19] and WHO [20]. The Quantitative Buffy Coat (QBC) technique of malaria detection as developed by Becton-Dickinson.The Human Immunodeficiency Virus (HIV) infection screening was carried out by the World Health Organization (WHO) approved double ELISA technique using Genie II HIV1/HIV-2 test kit (Bio-Rad, France) and Immunocomb II HIV-1/2 CombFirm (Orgenics, Israel). The Clinotech CRP semiquantitative technique as described by Clinotech Diagnostics (Richmond, Canada) was used. Haemoglobin elec- trophoresis was run with electrophoretic tank containing Tris-EDTA Borate buffer at $\mathrm{pH}$ 8.9. The electrophoresis was allowed to run for 15-20 minutes at $160 \mathrm{~V}$. Haemolysate from blood samples of known haemoglobin (i.e. AA, AS, AC) were run as controls.

\section{Statistical Analysis}

Statistical analysis was performed using the computer software Statistical Package for Social Science (SPSS) for windows version 11.0 (SPSS Inc, Chicago, USA). Statistical significance was set at $\mathrm{P} \leq 0.05$.

\section{RESULTS}

A total of 1371 pregnant women aged 15 to 48 years were studied (mean \pm SEM, $29.37 \pm 0.126$ yrs). Parity ranged from 0 to 9 (mean \pm SEM, $1.06 \pm 0.035$ per woman) $602(43.91 \%)$ were nulliparous, $389(28.37 \%)$ had one child each; 209 (15.24\%) had two children each; 83 (6.05\%) had three children each and $88(6.42 \%)$ had four and above (Table 1).

Table 2 shows the trimester/gestational age at recruitment, $249(18.16 \%)$ were in their first trimester (mean \pm SEM, $10.09 \pm 0.134$ weeks $), 712(51.93 \%)$ for second trimester (mean \pm SEM, $20.32 \pm 0.126$ weeks) and 410 $(29.91 \%)$ for third trimester (mean \pm SEM, $30 \pm 0.160$ weeks). Overall mean gestational age was $21.64 \pm 0.211$ weeks (median 20 weeks).

Haemoglobin $\mathrm{Hb}$ concentration ranged from $4.3 \mathrm{~g} / \mathrm{dl}$ to $17.0 \mathrm{~g} / \mathrm{dl}($ mean \pm SEM, $11.62 \pm 0.033 \mathrm{~g} / \mathrm{dl}) .318$ of the pregnant women had haemoglobin values less than $11.0 \mathrm{~g} / \mathrm{dl}$ $(\mathrm{Hb}<11.0 \mathrm{~g} / \mathrm{dl})$ representing $23.2 \%(95 \% \mathrm{CI} ; 11.55-11.68)$. Two samples were insufficient to be included in the aetiological studies. The remaining 316 anaemic pregnant women constituted the sub-sample study population for the aetiological assessment while 60 apparently healthy nonpregnant women aged between 18 and 40 years (mean \pm SEM, $26.07 \pm 0.68 \mathrm{yrs}$ ) constituted the control group. The mean $\mathrm{Hb}$ concentration of $12.57 \pm 0.11 \mathrm{~g} / \mathrm{dl}$ for the nonpregnant control women was significantly higher than that the mean of $10.04 \pm 0.5 \mathrm{~g} / \mathrm{dl}$ recorded for the pregnant women $(\mathrm{p}<0.05)$. The results also revealed $16.7 \%$ of the control group to be anaemic $(\mathrm{Hb}<12.0 \mathrm{~g} / \mathrm{dl}$; mean $\pm \mathrm{SEM}$, $11.57 \pm 0.174 \mathrm{~g} / \mathrm{dl})$. The difference in percentages of anaemia between the non-pregnant control group (16.7\%) and the pregnant group $(23.2 \%)$ was found to be statistically significant $(\mathrm{P}<0.05)$. 
Table 2. Characteristics of the Anaemic Pregnant Women According to Age Group, Trimesters and cut-offs Hb<11.0g/dl and $\mathbf{H b}<10.0 \mathrm{~g} / \mathrm{dl}$

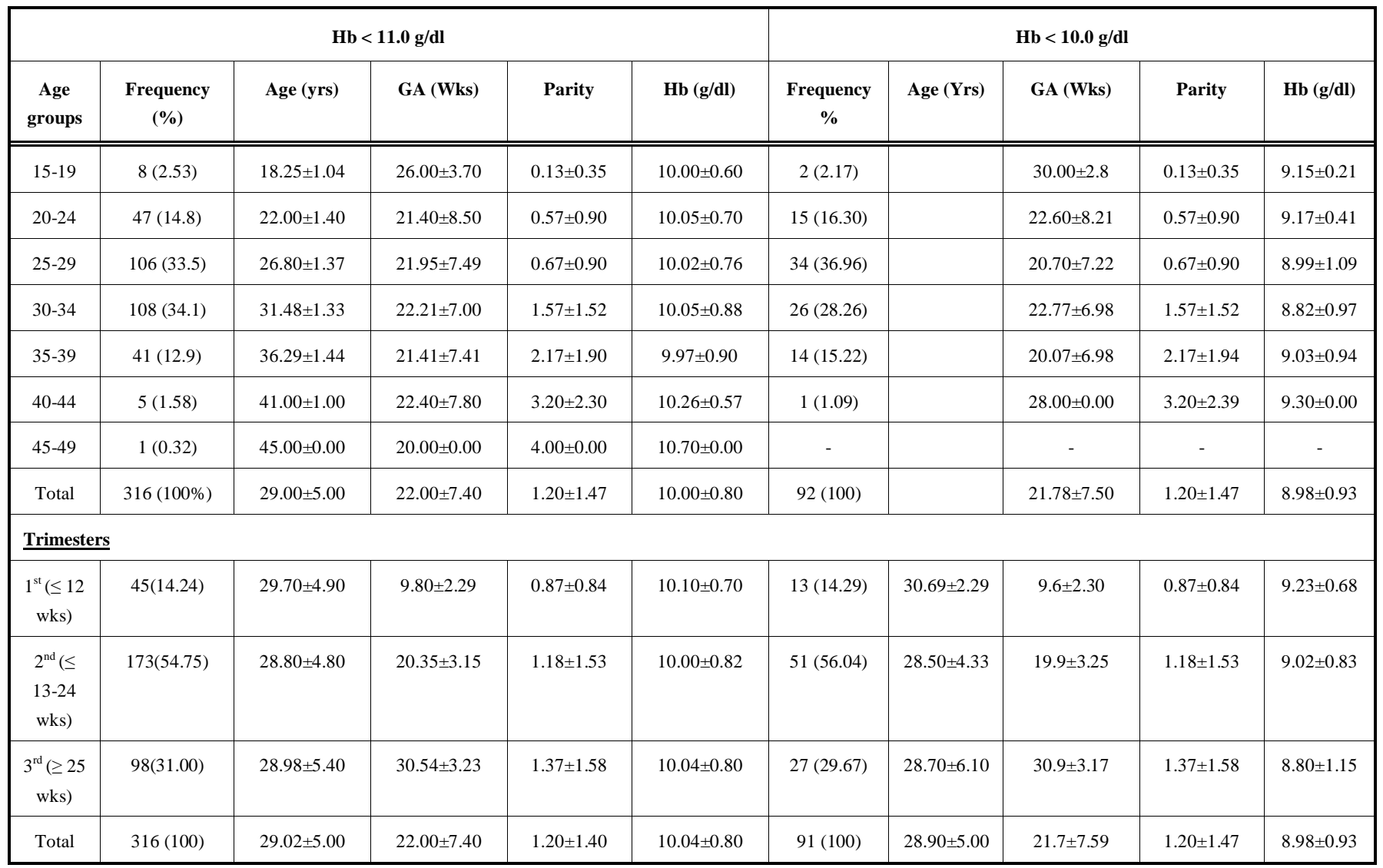

Table 3. Distribution of Anaemic Pregnant Women According to Severity of Anaemia

\begin{tabular}{|c|c|c|c|c|c|}
\hline \multirow{2}{*}{ Degree } & \multicolumn{2}{|c|}{$\mathrm{Hb}<11.0 \mathrm{~g} / \mathrm{dl}$} & \multicolumn{2}{|c|}{$\mathrm{Hb}<10.0 \mathrm{~g} / \mathrm{dl}$} & \multirow{2}{*}{ P value } \\
\hline & Range & Frequency $(\%)$ & Range & Frequency & \\
\hline Moderate & $7.0-8.9$ & $20(6.3)$ & $6.0-7.9$ & $8(8.7)$ & $>0.05$ \\
\hline Severe & $<7.0$ & $3(0.9)$ & $<6.0$ & $1(1.1)$ & $>0.05$ \\
\hline
\end{tabular}

The distribution of anaemic pregnant women according to severity of anaemia based on $\mathrm{Hb}<11 \mathrm{~g} / \mathrm{dl}$ and $\mathrm{Hb}<10 \mathrm{~g} / \mathrm{dl}$ cut-offs is as shown in Table 3. There is no significant difference when the two cut-off values were compared $(\mathrm{P}>0.05)$. Table 4 shows the prevalence of malaria parasite and HIV according to the severity of anaemia and based on the two cut-off values. Table $\mathbf{5}$ shows the prevalence of haemoglobinopathies among the entire study population. Homozygous (HbSS) sickle cell disease accounted for $0.6 \%$ of the pregnant population.

\section{DISCUSSION AND CONCLUSION}

According to WHO standards, anaemia in pregnancy is present when the haemoglobin concentration in the peripheral blood is less than $11.0 \mathrm{~g} / \mathrm{dl}$. Anaemia, $(\mathrm{Hb}<11.0 \mathrm{~g} / \mathrm{dl})$ was found to be present in $23.2 \%$ of the pregnant women in this study, of which $92.8 \%$ had mild anemia ( $\mathrm{Hb} 9-10 \mathrm{~g} / \mathrm{dl}$ ),
$6.3 \%$ had moderate anaemia $(\mathrm{Hb} 7.0-8.9 \mathrm{~g} / \mathrm{dl})$ and $0.9 \%$ had severe anaemia $(\mathrm{Hb}<7.0 \mathrm{~g} / \mathrm{dl})$. This finding is contrary to the $79.1 \%$ overall prevalence found among pregnant first-time attenders in Calabar [1]. It is also lower than the $29 \%$ prevalence reported by Aluka et al. [21] in Aba, Nigeria. For the fact that the population mean of all the pregnant women studied had $\mathrm{Hb}$ value of $11.62 \pm 1.21 \mathrm{~g} / \mathrm{dl}$, a case can be made for setting a cut-off value at $10.0 \mathrm{~g} / \mathrm{dl}$ for anaemia in pregnancy among Nigerian pregnant women. In support of this notion is the fact that in many developing countries, the vast majority of women with $\mathrm{Hb}$ values around $10 \mathrm{~g} / \mathrm{dl}$ are apparently healthy and symptom free and perinatal mortality rates are no different from what they are at higher haemoglobin levels. Only haemoglobin values $<10.0 \mathrm{~g} / \mathrm{dl}$ are likely to reflect inadequate maternal nutritional status with respect to iron, folic acid and other micronutrients [22]. A prevalence of $6.7 \%$ was obtained in this study using $\mathrm{Hb}$ values < 
Table 4. Distribution of Malaria Parasite and HIV Seropositivity According to Severity of Anaemia

\begin{tabular}{|c|c|c|c|c|}
\hline Severity of Anaemia & \multicolumn{2}{|c|}{ Malaria parasite } & \multicolumn{2}{|c|}{ HIV } \\
\hline Moderate & $8(12.5)$ & $3(11.1)$ & $3(11.1)$ & $1(7.7)$ \\
\hline Severe & $0(0)$ & $0(0)$ & $0(0)$ & $0(0)$ \\
\hline
\end{tabular}

The mean of $\mathrm{Hb}$ of subjects with single infection $(9.8 \mathrm{~g} / \mathrm{dl})$ was lower than those with dual infection $10.1 \mathrm{~g} / \mathrm{dl}(\mathrm{F}-\mathrm{test} 13.5, \mathrm{DF}=1, \mathrm{p}<0.0001)$.

$10.0 \mathrm{~g} / \mathrm{dl}$ of which $44(13.9 \%)$ were in the first trimester of pregnancy, $174(55.1 \%)$ were in the second trimester and $98(31.0 \%)$ were in the third trimester. Majority of these subjects $(90.2 \%)$ were mildly anaemic, $8.7 \%$ were moderately anaemic while $1.1 \%$ were severely anaemic.

Table 5. Prevalence of Haemoglobinopathies Among the Study Participants

\begin{tabular}{|c|c|}
\hline Haemoglobin Type & $\mathbf{n}(\boldsymbol{\%})$ \\
\hline \hline HbAA & $1137(82.9)$ \\
\hline HbAS & $226(16.5)$ \\
\hline HbSS & $8(0.6)$ \\
\hline
\end{tabular}

On the contrary, the incidence of anaemia in pregnancy in a hospital based population in Enugu, Nigeria was found to be $30.6 \%$ (using $\mathrm{Hb}<10.0 \mathrm{~g} / \mathrm{dl}$ ) and $67.4 \%$ using the minimum WHO acceptable standard of haemoglobin value less than $11 \mathrm{~g} / \mathrm{dl}$ [23] while a prevalence of $29.15 \%$ out of 533 pregnant women (using $\mathrm{PCV} \leq 30 \%$ ) was found at the antenatal clinic at Ogun state University Teaching Hospital, Sagamu, Nigeria. In Karachi (Pakistan), out of 709 pregnant women aged 16-45 years studied at the time of their first clinic attendance, $122(17 \%)$ were found to be anaemic using haemoglobin concentration below $10 \mathrm{~g} / \mathrm{dl}$ [24]. The $6.7 \%$ prevalence rate found in this study was lower than the $45 \%$ found in Papau New Guinea [25]. The reason for the differences might be improved awareness of how to stay healthy or differences in the aetiological factors inherent in the populations concerned.

The prevalence of anaemia using a cut off point of $\mathrm{Hb}<10.5 \mathrm{~g} / \mathrm{dl}$ was $60 \%$ in antenatal clinics in Dar es Salaam in 1990-1992 [26]. The prevalence of anaemia $(\mathrm{Hb}<11.0 \mathrm{~g} / \mathrm{dl})$ during pregnancy in Burkina Faso West Africa was reported to be $66 \%$ [27]. The observed prevalence of the severity as mild, moderate and severe anaemia was $30.8 \%, 33.5 \%$ and $1.7 \%$ respectively. Urassa et al. [28] found a prevalence rate of $69 \%$ using the WHO criteria of $\mathrm{Hb}<11.0 \mathrm{~g} / \mathrm{dl}$ for anaemia in the Rufiji district of Tanzania.

The prevalence of severe anaemia $\mathrm{Hb}<7.0 \mathrm{~g} / \mathrm{dl}$ using the WHO cut-off point of $\mathrm{Hb}<11.0 \mathrm{~g} / \mathrm{dl}$ and $\mathrm{Hb}<6.0 \mathrm{~g} / \mathrm{dl}$ when using our local cut-off point of $\mathrm{Hb}<10.0 \mathrm{~g} / \mathrm{dl}$ in this study were $0.9 \%$ and $1.1 \%$ respectively. These were lower than that previously reported in 2001 from Western Kenya (6.8\%) for third trimester anaemia in asymptomatic pregnant women. Since pregnant women with clinical symptoms of severe anaemia were excluded from participation in this study, the prevalence of severe anaemia reported in this study is likely to be an under estimation of the rate in the overall antenatal clinic population. This low prevalence rate can also be attributed to general health consciousness and widespread use of haematinics and prophylactic antimalarials prior to booking for antenatal care services of the hospital. It is a common practice in Nigeria for women in particular to place themselves on haematinics and antimalarial drugs.

There was no difference in mean haemoglobin concentration among maternal age groups and this is in agreement with the findings of Jackson et al. [29] in Zaire but in contrast to Hinderaker et al. [30]. This study also found increasing $\mathrm{Hb}$ with increasing parity and this corroborates previous reports $[23,29]$ and contrary to the reports by Hinderaker et al. [30]. It was expected that anaemia in pregnancy would tend to increase with rising parity owing to repeated drain on the iron reserves. In fact, multiparty, especially when the pregnancies have occurred in quick succession is traditionally regarded as a cause of anaemia in pregnancy. However this study found no consistent relationship between rising parity and the incidence of anaemia at booking. Perhaps, following the experience gained from the first pregnancy and the consequent increased awareness of the value of haematinics and good diet, as well as increased interaction with other pregnant women at the antenatal clinic, the effects of these may to some extent neutralize those of rising parity. This may imply that childbearing per se does not have long term detrimental effects on the woman's haematological status. This study also failed to observe any relationship between prevalence of anaemia and increasing gestational age, implying that all pregnant women were prone to anaemia throughout the gestational period, thus early booking for antenatal care would serve as an important preventive measure in pregnancy.

The difference in the prevalence of anaemia between the non-pregnant group (16.7\%) and the pregnant group $(23.2 \%)$ was found to be statistically significant $(\mathrm{p}<0.05)$. This finding agrees with the Expert Consultative Group on Determinants of Anaemia [31] that the prevalence of anaemia is higher in pregnant women than in non-pregnant women. The $16.7 \%$ prevalence of anaemia among the non-pregnant women suggests that mild anaemia is often present among apparently healthy non-pregnant women of reproductive age in our environment. The pregnant women with $23.2 \%$ prevalence indicate moderate anaemia of public health significance as values between 20 and $39.9 \%$ are considered moderate by WHO standard [20]. 
The presence of maternal malaria at enrollment was $20.3 \%$ with a mean $\mathrm{Hb}$ of $9.81 \pm .92 \mathrm{~g} / \mathrm{dl}$ as against malaria negativity of $10.09 \pm 0.70 \mathrm{~g} / \mathrm{dl}(\mathrm{p}>0.05)$. This is in agreement with Brabin et al. [12] who could not find any statistical difference between the two groups. However, the odds ratio shows association with significant reduction in haemoglobin concentration among the malaria positives (RR 0.55, $95 \%$ CI $0.36-0.85, \chi^{2}=7.02, p<0.05$ ). This finding suggested a causal relationship between asymptomatic malaria positivity and a reduction in haemoglobin concentration. The prevalence of $P$. falciparum was highest in the second trimester $(46.9 \%)$. This may probably be due to the fact that most pregnant women do not go for antenatal clinic until the second trimester. It may as well suggest that immunosuppression is greatest in the second trimester of pregnancy.

Eight of the $316(2.5 \%)$ anaemic pregnant women had malaria and HIV co-infection in the 20-34 years age range among the primigravidae and secundigravidae in their second and third trimesters. This finding confirms that because of the high prevalence of HIV and malaria in sub-Saharan Africa, co-infection is possible [32]. This has important implications since both HIV and malaria are among the leading cause of morbidity in pregnancy in Africa.

The prevalence of HIV seropositivity in the study population was $3.5 \%$ while the prevalence rate among anaemic pregnant women was $8.5 \%$, thus this study observed a statistically significant higher prevalence of HIV seropositivity in the sample of anaemic women than the prevalence of the entire pregnant women $(\mathrm{p}<0.05)$. Although the relative risk of HIV seropositivity increased some what with the prevalence of anaemia (Risk Ratio 0.44; 95\% CI 021-0.89) no significant association was found between the degree of anaemia and HIV serostatus among the study women with anemia. However, logistic regression analysis showed that anaemia was significantly and independently related to HIV infection. This finding corroborates previous reports [33, 34].

Anaemia of infection/inflammatory processes was assessed with elevated serum C-reactive protein (s-CRP). Elevated serum C-reactive protein (> 20mg/L) was found to be more common with the anaemic pregnant women (40.2\%) compared with (6.7\%) among the non-pregnant control group ( $<0.001)$. This implies that anaemia of infection was present in $40.2 \%$ of the pregnant women. Parasitic, bacterial and viral infection may account for this high figure among our pregnant women. This prevalence rate is comparable with the findings of Bondevik et al. [35] but at variance with Usanga et al. [1].

Two women $(0.6 \%)$ had sickle cell anaemia (homozygous $\mathrm{HbSS}$ ) despite a $16.5 \%$ prevalence of sickle cell trait (HbAS). This finding was lower than the $3 \%$ reported by Fleming among 37 pregnant Zambian women with severe anaemia [36].

Knowledge of the relative importance of the different aetiological factors should form the basis for intervention strategies to control anaemia.

\section{REFERENCES}

[1] Usanga EA, Chilaka M, Archibong EI. Prevalence of iron deficiency anaemia in Nigerian pregnant women. J Med Lab Sci 1994; 4: 107-113.
[2] Shulman CE, Graham WJ, Jilo H, Lowe BS, New L, Obiero J, Snow RW, Marsh K. Malaria is an important cause of anaemia in primigravidae: evidence from a district hospital in coastal Kenya. Trans R Soc Trop Med Hyg 1996; 90: 535-539.

[3] Van den Broek NR, Letsky E. Aetiology of anaemia in pregnancy in south Malawi, Am J Clin Nutr 2000; 72: 247S-256S.

[4] World Health Organization Iron Deficiency Anaemia Assessment, Prevention, and Control. A guide for programme managers, 2001 WHO/NHD/01.

[5] Marchant TJ. The health of pregnant women in rural Tanzania with specific emphasis on anaemia and the impact of socially marketed insecticide treated bednets. Inaugural dissertation. Basel 2002; pp. $1-188$.

[6] Crawley J. Reducing the burden of anaemia in infants and young children in malaria endemic countries of Africa: from evidence to action. Am J Trop Med Hyg 2004; 71: 25-34.

[7] Haas JD, Brownlie TT. Iron deficiency and reduced work capacity: a critical review of the research to determine a causal relationship. J Nutr 2001; 131: 676S-688S.

[8] Zucker JR, Lackritz EM, Ruebush TK, et al. Anaemia, blood transfusion practices, HIV and mortality among women of reproductive age in western Kenya. Trans R Soc Trop Med Hyg 1994; 8: 173

[9] Lackritz EM. Prevention of HIV transmission by blood transfusion in the developing world: achievements and continuing challenges. AIDS 1998; 12: S81-S86.

[10] Ross J, Thomas EL. Iron Deficiency Anaemia and Maternal Mortality. Profiles 3, Working Notes Series No. 3. Washington, D.C.: Academy for Educational Development, 1996.

[11] UNICEF State of the World's Population 1994, New York: UNFPA, 1998

[12] Brabin BJ, Ginny M, Sapau J, Galme K, Paino J. Consequences of maternal anaemia on outcome of pregnancy in a malaria endemic area of Papua New Guinea. Annals Trop Med Parasitol 1990; 84: 11-24.

[13] Macleod J, Rhode R, Retrospective follow-up of maternal Deaths and their associated risk factors in a rural district of Tanzania. Trop Med Intl Health 1998; 3: 130-137.

[14] Axemo P, Liljestrand J, Bergstrom S, Gebre-Medhin M. Aetiology of late fetal death in Maputo. Gynaecol Obstet Invest 1995; 39: 103-109.

[15] Brabin BJ, Premji Z, Verhoeff F. An analysis of anaemia and child mortality. J Nutr 2001; 132: 636S-645S.

[16] Scholl TO, Hediger ML, Fischer RL, Shearer JW. Anaemia Vs iron deficiency: increased risk of preterm delivery in a prospective study. Am J Clin Nutr 1992; 55: 985-988.

[17] Cook JD Iron deficiency anaemia. Baillieres Clin Haem 1994; 7 : 787-804.

[18] Barbara JB, Bates I. Basic Haematological techniques. In: Dacie and Lewis Practical Haematology. ${ }^{\text {th }}$ ed. Churchill Livingstone. 2001; pp. 19-48.

[19] International Committee for Standardization in Haematology (ICSH). Proposed international standard of ferritin for serum ferritin assay. Brit J Haem 1985; 61: 61-63.

[20] World Health Organization. Iron Deficiency Anaemia Assessment, Prevention, and Control. A guide for programme managers 2001; WHO/NHD/01.

[21] Aluka C, Amadi AN, Kamanu CI, Fejyi-Waboso PA. Anaemia in pregnancy in Abia State University Teaching Hospital Aba. J Med Invest Pract 2001; 2: 58-61.

[22] Rasmussen KM. Is there a causal relationship between iron deficiency anaemia and weight at birth, length of gestation and perinatal mortality? J Nutr 2001; 131: 5905-6035.

[23] Iloabachie GC, Meniru GI. The increasing incidence of anaemia in pregnancy in Nigeria. Orient J Med 1990; 2: 194-197.

[24] Saadiya AK, Mohammed K, Javaid HR, Sadiqua NJ, Rubina IS. Anaemia in pregnancy - a study of 709 women in Karachi. Trop Doctor 1990; 20: 184-185.

[25] Amoa AB, Klufio CA, Kariwiga G, Heywood S. Antenatal haemoglobin profile at the Port Moresby General Hospital. Papua New Guinea Med J 1998; 41: 119-125.

[26] Massawe S, Urassa E, Lindmark G, Moller B, Nystrom L. Anaemia in pregnancy: a major health problem with implications for maternal health care. Afr J Health Sci 1996; 3: 126-132

[27] Meda N, Mandelbrot L, Cartoux M, Dao B, Ouangre A, Dabis F. Anaemia during pregnancy in Burkina Faso, West Africa, 1995- 
1996: prevalence and associated factors. Bull World Health Organ 1999; 77: 916-922.

[28] Urassa E, Massawe S, Lindmark G, Nystron L. Maternal mortality in Tanzania - medical causes are interrelated with socioeconomic and cultural factors. South Afr Med J 1996; 86: 436-444.

[29] Jackson DJ, Klee EB, Green SD, Mokili JL, Elton RA, Cutting WA. Severe anaemia in pregnancy: a problem of primigravidae in rural Zaire. Trans R Soc Trop Med Hyg 1991; 85: 829-832.

[30] Hinderaker SG, Olsen BE, Bergsjo P, Lie RT, Gasheka P, Kwale G. Anaemia in pregnancy in the highlands of Tanzania. Acta Obstet Gynecol 2001; 80: 18-26.

[31] Expert Consultative Group on Determinants of Anaemia WHO Report Series (1997); No 17.

[32] Van den Broek NR, White SA, Neilson JP. The relationship between asymptomatic human immunodeficiency virus infection and the prevalence and severity of anaemia in pregnant Malawian women. Am J Trop Med Hyg 1998; 59: 1004-1007.
[33] Ter Kuile FO, Parise ME, Verhoeff FH, Udhayakumar V, Newman RD, Van Eijk AM, Rogerson SJ, Steketee RW. The burden of coinfection with human immunodeficiency virus type 1 and malaria in pregnancy women in sub-Saharan Africa. Am J Trop Med Hyg 2004; 7: 41-54.

[34] Van Eijk AM, Ayisi JG, ter Kuile FO, Misore A, Otieno JA, Kolezak MS. Human immunodeficiency virus seropositivity and malaria as risk factors for third-trimester anaemia in asymptomatic pregnant women in western Kenya. Am J Trop Med Hyg 2001; 65: 623-630.

[35] Bondevik GT, Eskeland B, Ulvik RJ, Ukstein M, Lie RT, Schneede J, Kvale G. Anaemia in pregnancy: Possible causes and risk factors in Nepali women. Eur. J Clin Nutr 2000; 54: 3-8.

[36] Fleming AF. Anaemia in pregnancy in tropical Africa. Trans R Soc Trop Med Hyg 1989; 83: 441-448. 